\title{
Predominance of hexamethylated 6-methyl branched glycerol dialkyl glycerol tetraethers in the Mariana Trench: source and environmental implication
}

\author{
Wenjie Xiao ${ }^{1}$, Yasong Wang ${ }^{1}$, Yongsheng $\mathrm{Liu}^{1}$, Xi Zhang ${ }^{1}$, Linlin Shi ${ }^{1}$, and Yunping $\mathrm{Xu}^{1,2}$ \\ ${ }^{1}$ Shanghai Engineering Research Center of Hadal Science \& Technology, College of Marine Sciences, \\ Shanghai Ocean University, Shanghai 201306, China \\ ${ }^{2}$ Key Laboratory of Sustainable Exploitation of Oceanic Fisheries Resources, Ministry of Education, \\ Shanghai Ocean University, Shanghai 201306, China
}

Correspondence: Yunping Xu (ypxu@ shou.edu.cn)

Received: 26 September 2019 - Discussion started: 11 October 2019

Revised: 19 March 2020 - Accepted: 23 March 2020 - Published: 17 April 2020

\begin{abstract}
Branched glycerol dialkyl glycerol tetraethers (brGDGTs) are useful molecular indicators for organic carbon (OC) sources and the paleoenvironment. Their application in marine environments, however, is complicated because of a mixed terrestrial and marine source. Here, we examined brGDGTs in sediments from the Mariana Trench, the deepest ocean without significant terrestrial influence. Our result shows a strong predominance of hexamethylated 6-methyl brGDGT (IIIa') $(73.40 \pm 2.39 \%$ of total brGDGTs) and an absence of 5-methyl brGDGTs, different from previously reported soils and marine sediments that comprised both 5-methyl and 6-methyl brGDGTs. This unique feature, combined with high $\delta^{13} \mathrm{C}_{\mathrm{OC}}(-19.82 \pm$ $0.25 \%)$, low OC/TN ratio $(6.72 \pm 0.84)$, low branched and isoprenoid tetraether (BIT) index $(0.03 \pm 0.01)$, and high acyclic hexa- / pentamethylated brGDGT ratio (7.13 \pm 0.98$)$, support that brGDGTs in the Mariana Trench sediments are autochthonous rather than terrestrial products. The compiling of literature data shows that the enhanced fractional abundance of hexamethylated 6-methyl brGDGTs is a common phenomenon in continental margins when the marine influence was intensified. The cross plot of acyclic hexa/ pentamethylated brGDGT ratio and fractional abundance of brGDGT IIIa' provide a novel approach to distinguish terrestrial and marine-derived brGDGTs.
\end{abstract}

\section{Introduction}

Glycerol dialkyl glycerol tetraethers (GDGTs), including isoprenoidal GDGTs (iGDGTs) and branched GDGTs (brGDGTs), are widely distributed biomarkers in terrestrial and marine settings (De Rosa and Gambacorta, 1988; Sinninghe Damsté et al., 2000). iGDGTs containing an isoprenoid carbon skeleton are predominantly synthesized by archaea belonging to the phylum Thaumarchaeota (Sinninghe Damsté et al., 2002; Schouten et al., 2008; Knappy et al., 2011; Zeng et al., 2019). Unlike iGDGTs, brGDGTs consisting of four to six methyl groups and zero to two cyclopentane moieties are synthesized by some bacteria including, but not limited to, Acidobacteria (Sinninghe Damsté et al., 2011). These bacteria are able to alter the degree of methylation and cyclization of brGDGTs with changing ambient environmental conditions (Weijers et al., 2007b). A survey for global soils reveals that the cyclization of branched tetraethers (CBT) correlates with soil $\mathrm{pH}$, while the methylation of branched tetraethers (MBT) is dependent on mean annual air temperature (MAT) and to a lesser extent on soil $\mathrm{pH}$ (Weijers et al., 2007b; De Jonge et al., 2014a), leading to the development of brGDGT-based MBT-CBT proxies for $\mathrm{pH}$ and MAT. BrGDGTs are generally more abundant in peats and soils than marine sediments, and they decrease from coastal to distal marine sediments (Hopmans et al., 2004; Schouten et al., 2013). Thus, brGDGTs and iGDGTs were thought to be biomarkers for terrestrial (particularly soil) and marine organic matter, respectively. This source differ- 
ence led to the development of the branched vs. isoprenoid tetraether (BIT) index for estimation of terrestrial (soil) OC in marine sediments (Hopmans et al., 2004).

BrGDGT-derived proxies such as BIT, MBT, and CBT have been used to assess OC sources (Herfort et al., 2006; Kim et al., 2006; Loomis et al., 2011; Wu et al., 2013), soil $\mathrm{pH}$, and MAT in diverse environments (Weijers et al., 2007a; Sinninghe Damsté et al., 2008; Peterse et al., 2012; Yang et al., 2014). However, one weakness of these proxies is the source uncertainty. Although brGDGTs were assumed to be specific for soil and peat bacteria (Hopmans et al., 2004; Weijers et al., 2007a, b), different compositions of brGDGTs among rivers (Zhang et al., 2012; Zell et al., 2013, 2014a), lakes (Sinninghe Damsté et al., 2009; Tierney and Russell, 2009; Loomis et al., 2011; Buckles et al., 2014), marine waters (Liu et al., 2014; Xie et al., 2014; Zell et al., 2014b), and sediments (Peterse et al., 2009; Zhu et al., 2011; Xiao et al., 2016) suggest multiple sources. Besides temperature and pH, oxygen (Qin et al., 2015) and moisture (Dang et al., 2016a) can also influence the composition of GDGTs. For example, in a Swiss lake (Lake Lugano), the vertical pattern of brGDGTs and bacterial 16S rRNA gene data suggested that brGDGTs were synthesized by multiple groups of bacteria thriving under contrasting redox regimes (Weber et al., 2018).

Weijers et al. (2007b) detected nine brGDGT isomers in peat and soils and assigned them to 5-methyl brGDGTs. De Jonge et al. (2013) developed a new chromatographic method using two silica columns and found that the brGDGTs previously identified as 5-methyl brGDGTs were actually mixtures of 5-methyl and 6-methyl isomers. As a result, the number of brGDGTs increased from 9 to 15, which was further expanded after the identification of 7-methyl brGDGTs (Ding et al., 2016). The analytical improvement has opened a window for the redefinition and recalibration of brGDGTderived proxies (De Jonge et al., 2014a; Xiao et al., 2015). Adopting the new chromatographic method, several studies have provided clues of in situ production of brGDGTs in rivers (De Jonge et al., 2014b, 2015), lakes (Weber et al., 2015, 2018), and marine sediments (De Jonge et al., 2016; Sinninghe Damsté, 2016). However, rivers, lakes, and marginal seas are usually subject to terrestrial influence, making it difficult to distinguish allochthonous terrestrial and autochthonous aquatic contributions to the brGDGT pool.

Here, we choose the Challenger Deep, Mariana Trench, to study brGDGTs in marine settings. This deepest trench $(11000 \mathrm{~m})$ is remote from any landmass and has no significant terrestrial influence (Jamieson, 2015). Our goals are (1) to determine the composition and concentration of brGDGTs in the Mariana Trench sediments and constrain their source and (2) to characterize in situ production of brGDGTs in marine sediments and assess their environmental implication.

\section{Material and methods}

\subsection{Study area and samples}

The Mariana Trench is formed as the subduction of the Pacific plate beneath the eastern edge of the Philippine Sea plate. It has a total length of ca. $2500 \mathrm{~km}$ and a mean width of $70 \mathrm{~km}$ (Fryer, 1996). The Challenger Deep is located on the southern rim of the Mariana Trench and has a water depth of $11000 \mathrm{~m}$. The Mariana Trench is overlain by extremely oligotrophic waters with annual primary production of $59 \mathrm{~g} \mathrm{C} \mathrm{m}^{-2} \mathrm{yr}^{-1}$ (Jamieson, 2015). However, sediments in the Challenger Deep were found to support elevated microbial activity compared to adjacent abyssal plains (Glud et al., 2013). This characteristic has been attributed to unique V-shaped geometry, intense seismic activity, and high-frequency fluid dynamics within the trench that promote lateral transport of sediments and organic matter from shallow regions into the trench bottom (Jamieson, 2015; Xu et al., 2018).

During an expedition aboard RV Zhang Jian (December 2016 to February 2017), a sediment core (MT1, $11 \mathrm{~cm}$ long) was retrieved from the Challenger Deep using an autonomous $11000 \mathrm{~m}$ rated lander (Fig. 1). The core was immediately stored at $-20^{\circ} \mathrm{C}$ in a dark room until transported to the laboratory in Shanghai (China). The core was sliced at $1-2 \mathrm{~cm}$ intervals. All sediment samples $(n=10)$ were freezedried at $-40^{\circ} \mathrm{C}$ and homogenized by steel spatulas.

Besides the Mariana Trench sediments, a soil sample (Soil-1) from China grassland was analyzed. This soil sample was used for comparison of brGDGTs between soil and trench sediments.

\subsection{Lipid extraction and GDGT analyses}

Sediment samples $(0.5-2 \mathrm{~g})$ were mixed with an internal standard $\mathrm{C}_{46}$ GDGT (Huguet et al., 2006) and $15 \mathrm{~mL}$ of dichloromethane/methanol $(3: 1, v / v)$. After being ultrasonically extracted for $15 \mathrm{~min}$, the extracts were centrifuged ( $3000 \mathrm{rpm}, 5 \mathrm{~min}$ ), and the supernatants were decanted into clean flasks. This extraction was repeated three times. The combined extracts were concentrated by a rotary evaporator and further blown down to dryness under mild nitrogen streams. The total lipid extract was dissolved in hexane / isopropanol $(99: 1, v / v)$ and filtered through a $0.45 \mu \mathrm{m}$ PTFE filter. An Agilent ultrahigh-performance liquid chromatography - atmospheric pressure chemical ionization - triple quadruple mass spectrometry system (UHPLCAPCI-MS) was used for analysis of GDGTs. The separation of 5- and 6-methyl brGDGTs was achieved with two silica liquid chromatography (LC) columns in sequence $(150 \mathrm{~mm} \times 2.1 \mathrm{~mm} ; 1.9 \mu \mathrm{m}$, Thermo Finnigan; USA). The detailed instrumental parameters were described by Hopmans et al. (2016). The protonated ions were $m / z$ 1050, 1048, 1046, 1036, 1034, 1032, 1022, 1020, and 1018 for 


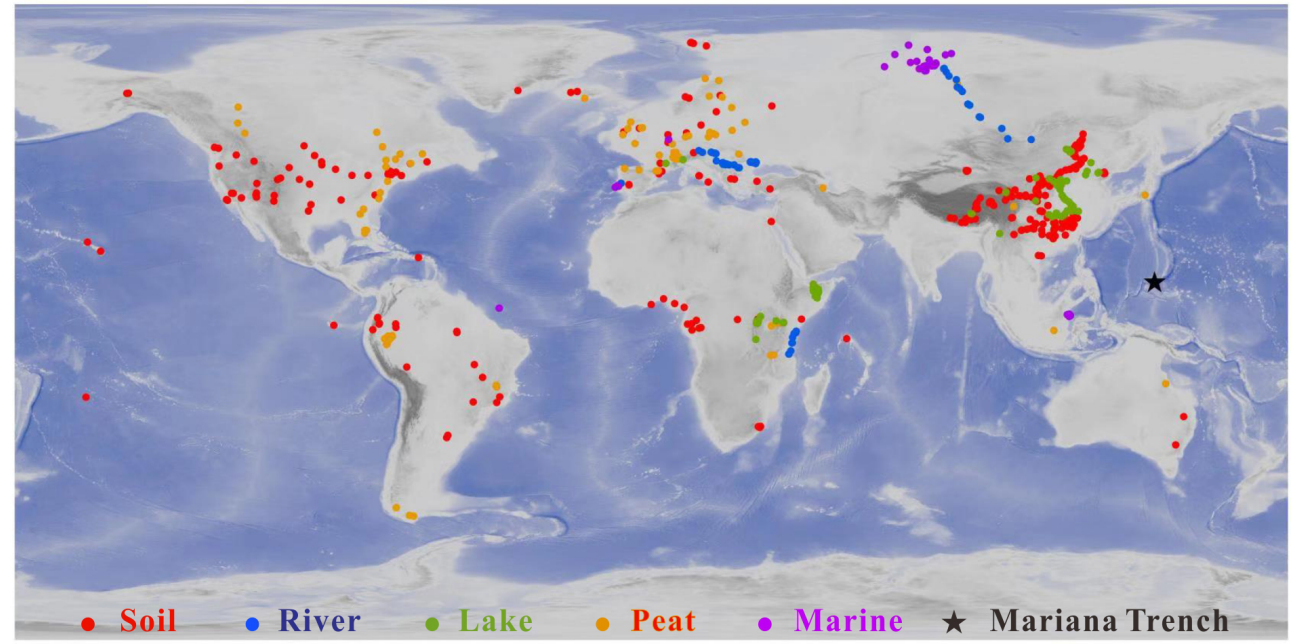

Figure 1. Location of the samples in this study. Red, orange, gray, blue and purple circles indicate globally distributed soil, river, lake, peat, and marine samples, respectively. Black star denotes the sediment core in the Mariana Trench. Detailed information is provided in the Supplement.

brGDGTs; 1302, 1300, 1298, 1296, and 1292 for iGDGTs; and 744 for $\mathrm{C}_{46}$ GDGT. Since the response factors of GDGTs were not determined due to the lack of authentic standard, we did not calculate the absolute concentration of GDGTs. Instead, we reported the relative concentration based on peak areas (pa) of respective GDGTs normalized to total GDGTs.

\subsection{GDGT-derived parameters}

The BIT index, ratio of acyclic hexa- to pentamethylated brGDGTs, and weighted average number of cyclopentane moieties for the tetramethylated brGDGTs (\#rings tetra) were calculated according to the definitions of Hopmans et al. (2004), Xiao et al. (2016), and Sinninghe Damsté (2016), respectively.

$$
\begin{aligned}
& \mathrm{BIT}=\left(\mathrm{Ia}+\mathrm{IIa}+\mathrm{IIIa}+\mathrm{IIa}^{\prime}+\mathrm{IIIa}^{\prime}\right) /(\mathrm{Ia}+\mathrm{IIa} \\
& \left.\quad+\mathrm{IIIa}+\mathrm{IIa}^{\prime}+\mathrm{IIIa}^{\prime}+\mathrm{Cren}\right) \\
& \sum \mathrm{IIIa} / \sum \mathrm{IIa}=\left(\mathrm{IIIa}+\mathrm{IIIa}^{\prime}\right) /\left(\mathrm{IIa}+\mathrm{IIa}^{\prime}\right) \\
& \text { \#rings }_{\text {tetra }}=(\mathrm{Ib}+2 \cdot \mathrm{Ic}) /(\mathrm{Ia}+\mathrm{Ib}+\mathrm{Ic})
\end{aligned}
$$

The roman numbers denote relative abundance of GDGTs that were depicted in Fig. 2.

\subsection{Bulk geochemical analysis}

About 1-2 $\mathrm{g}$ of each sediment sample was treated with $1 \mathrm{NHCl}$ to remove carbonates, rinsed with ultrapure water, and then freeze-dried. After having homogenized with an agate mortar and pestle, approximately $35-40 \mathrm{mg}$ of decarbonated sediments was analyzed using a model 100 isotope ratio mass spectrometer (Isoprime Corporation, Cheadle, UK) and a Vario ISOTOPE cube elemental analyzer
(Elementar Analysensysteme GmbH, Hanau, Germany). All isotopic data were reported in $\delta$ notation relative to Vienna Pee Dee Belemnite (VPDB). The intra-lab standard for normalizing stable isotopic composition of $\mathrm{OC}\left(\delta^{13} \mathrm{C}_{\mathrm{OC}}\right)$ was USG24 (graphite, $-16.05 \%$ ) (IAEA, Vienna, Austria). The average standard deviation of each measurement, determined by replicate analyses of two samples, was $\pm 0.004 \mathrm{wt} \%$ for organic carbon (OC) content, $\pm 0.031 \mathrm{wt} \%$ for total nitrogen (TN) content, and $\pm 0.03 \%$ for $\delta^{13} \mathrm{COC}_{\mathrm{OC}}$.

\subsection{Literature data compilation}

The dataset is composed of 2031 samples, including 634 soil samples, 473 peat samples, 88 river samples, 410 lake samples, and 426 marine samples (Fig. 1). The sample information was listed in the Supplement. The soil samples are from globally distributed soils (De Jonge et al., 2014a; Ding et al., 2015; Xiao et al., 2015; Yang et al., 2015; Lei et al., 2016; Wang et al., 2016, 2018, 2019; Li et al., 2018; Zang et al., 2018). The peat samples are from 96 different peatlands around the world (Naafs et al., 2017). The river samples are from the Danube River (Freymond et al., 2016), the Yenisei River (De Jonge et al., 2015), and the Tagus River (Warden et al., 2016). The lake samples are from east African lakes (Russell et al., 2018), Chinese lakes (Dang et al., 2016b, 2018; Li et al., 2017), Lake St Front (Martin et al., 2019), Lake Lugano, and other lakes in the European Alps (Weber et al., 2018). The marine samples are from Atlantic Ocean (Warden et al., 2016), the Kara Sea (De Jonge et al., 2015, 2016), the Berau River delta (Sinninghe Damsté, 2016), the Ceará Rise (Soelen et al., 2017), the North Sea (Dearing CramptonFlood et al., 2018), and the Mariana Trench (this study). The criteria for citing the literature data is that 5- and 6-methyl brGDGTs should be separated and quantified. It is noted that 

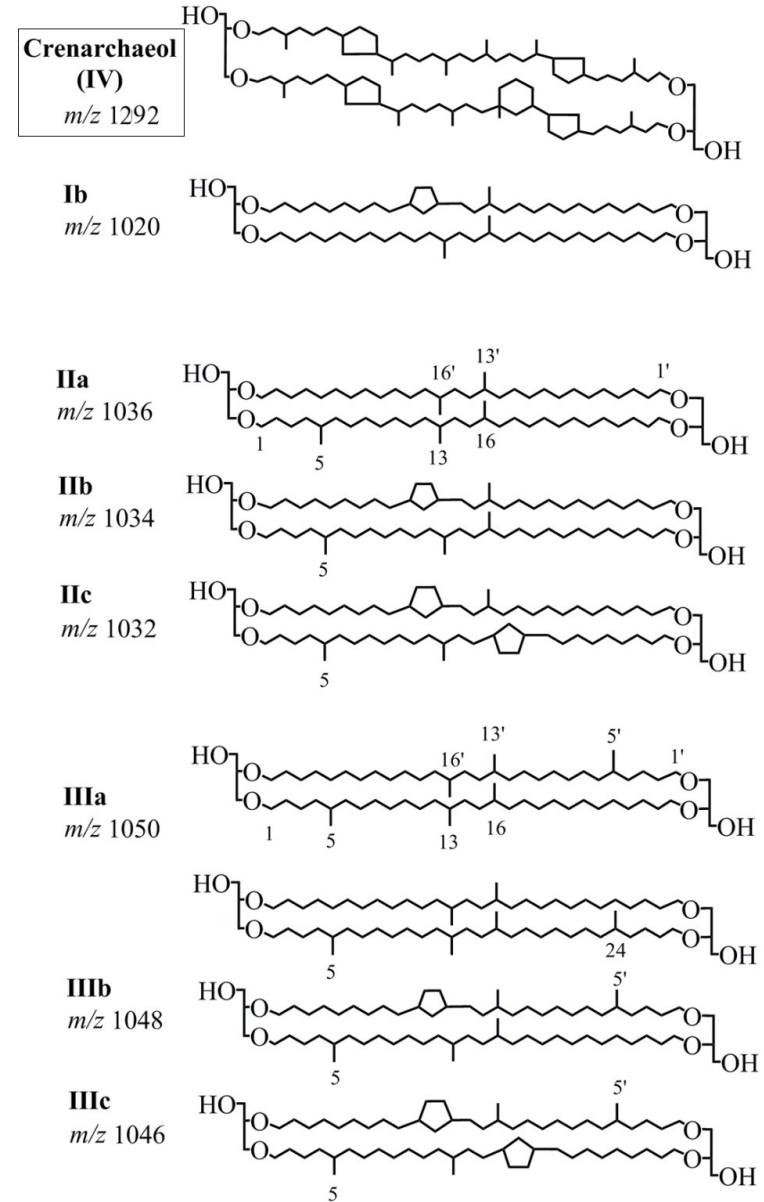

Figure 2. Chemical structures of brGDGTs and crenarchaeol.

two studies (Weber et al., 2018; Martin et al., 2019) have analyzed 5-, 6-, and 7-methyl brGDGTs, but due to very limited reports for 7-methyl brGDGTs they are not included in our literature dataset.

\subsection{Statistical analysis}

The SPSS package 22 (IBM, USA) was used for statistical analyses including Pearson correlation coefficient $(r)$ and one-way analysis of variance (ANOVA). The significance level was set at $p<0.05$.

\section{Results}

\subsection{Bulk geochemical parameters}

The OC content, TN content, molar ratio of OC to TN content $(\mathrm{OC} / \mathrm{TN})$, and $\delta^{13} \mathrm{C}_{\mathrm{OC}}$ are summarized in Table 1. The $\mathrm{OC}$ and TN contents of sediments varied between $0.26 \%$ and $0.31 \%$ with an average of $0.28 \pm 0.01 \%$ (mean $\pm \mathrm{SD}$; same hereafter) and between $0.04 \%$ and $0.06 \%(0.05 \pm 0.01 \%)$, respectively. The $\mathrm{OC} / \mathrm{TN}$ ratio and $\delta^{13} \mathrm{C}_{\mathrm{OC}}$ ranged from 5.62
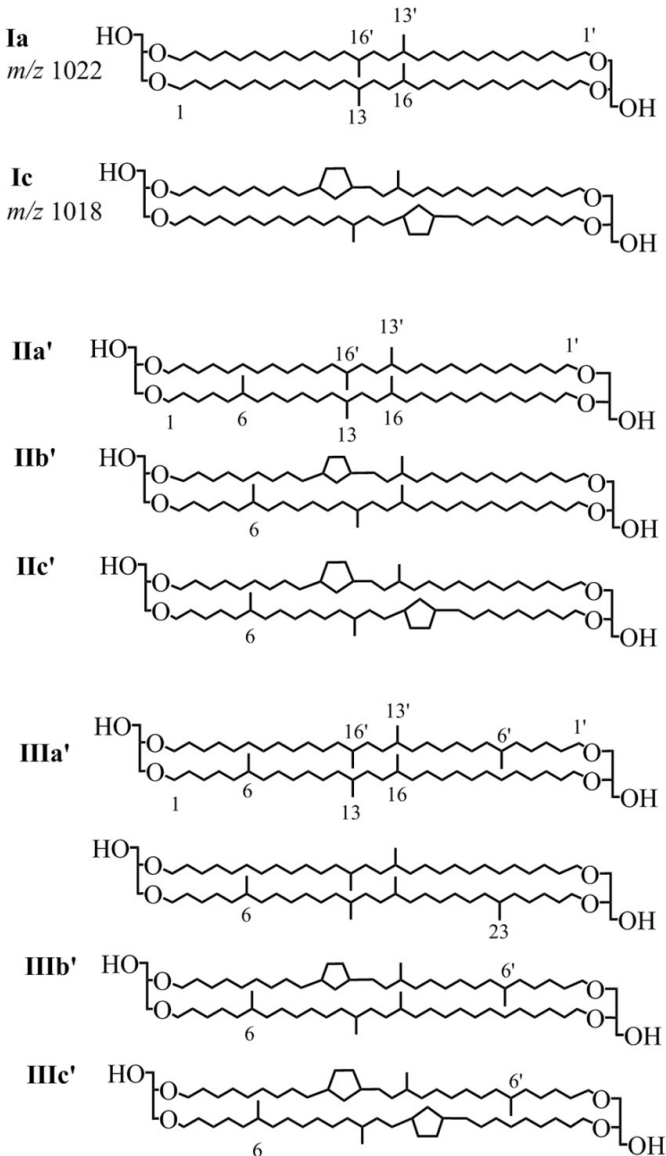

Table 1. Organic carbon (OC) content, total nitrogen (TN) content, molar ratio of $\mathrm{OC} / \mathrm{TN}$, and stable carbon isotopic composition $\left(\delta^{13} \mathrm{C}_{\mathrm{OC}}\right)$ in the Mariana Trench sediments.

\begin{tabular}{lrrrrr}
\hline $\begin{array}{l}\text { Sample } \\
\text { ID }\end{array}$ & $\begin{array}{r}\text { Depth } \\
(\mathrm{cm})\end{array}$ & $\begin{array}{r}\text { OC } \\
(\text { wt \%) }\end{array}$ & $\begin{array}{r}\text { TN } \\
(\text { wt } \%)\end{array}$ & $\begin{array}{r}\text { OC/TN } \\
(\mathrm{mol} / \mathrm{mol})\end{array}$ & $\begin{array}{r}\delta^{13} \mathrm{C}_{\mathrm{OC}} \\
(\% \circ)\end{array}$ \\
\hline MT1 & $0-2$ & 0.31 & 0.05 & 6.52 & -20.02 \\
MT2.5 & $2-3$ & 0.27 & 0.05 & 6.05 & -19.66 \\
MT3.5 & $3-4$ & 0.29 & 0.05 & 6.85 & -19.55 \\
MT4.5 & $4-5$ & 0.27 & 0.05 & 5.78 & -19.84 \\
MT5.5 & $5-6$ & 0.29 & 0.06 & 6.13 & -19.94 \\
MT6.5 & $6-7$ & 0.30 & 0.06 & 5.62 & -19.47 \\
MT7.5 & $7-8$ & 0.27 & 0.04 & 7.27 & -19.54 \\
MT8.5 & $8-9$ & 0.29 & 0.05 & 6.93 & -19.82 \\
MT9.5 & $9-10$ & 0.28 & 0.04 & 7.74 & -20.09 \\
MT10.5 & $10-11$ & 0.26 & 0.04 & 8.34 & -20.27 \\
\hline
\end{tabular}

to $8.34(6.72 \pm 0.84)$ and $-19.47 \%$ o to $-20.27 \%$ o $(-19.82 \pm$ $0.25 \%$ ), respectively. Both the $\delta^{13} \mathrm{COC}_{\mathrm{OC}}$ and $\mathrm{OC} / \mathrm{TN}$ ratio were comparable to previously reported levels for the southern Mariana Trench rim and slope $\left(\delta^{13} \mathrm{C}_{\mathrm{OC}},-20.48 \pm\right.$ $0.88 \%$; OC/TN, $7.00 \pm 1.76$ ) (Luo et al., 2017). 


\subsection{Composition and fractional abundance of GDGTs}

The fractional abundance of iGDGTs and brGDGTs is summarized in Table 2. iGDGTs were the dominant components, accounting for $96.8 \%$ to $98.6 \%$ of total GDGTs in Mariana Trench sediments. The proportion of brGDGTs was substantially lower than that of iGDGTs, ranging from $1.4 \%$ to $3.2 \%$. For all sediment samples, the BIT index remained at a low level $(0.03 \pm 0.01)$.

With improved chromatographic performance, 5- and 6methyl brGDGTs were completely separated (Fig. 3a, b). Interestingly, the mass chromatograms of the Mariana Trench sediment (MT-4) only showed a single peak for acyclic penta- $(m / z$ 1036; Fig. $3 c)$ and hexamethylated $(m / z$ 1050; Fig. 3d) brGDGTs. This feature is different from most previous studies showing two or more peaks (i.e., 5-, 6-, and even 7-methyl brGDGTs) occurred in soils, lake, and marine sediments (e.g., De Jonge et al., 2013; Xiao et al., 2015; Ding et al., 2016). In order to determine the structure of brGDGTs, we compared the mass spectra of brGDGTs between MT4 and Soil-1. The soil sample (Soil-1) has been reported to contain both 5-methyl brGDGTs (major component) and 6methyl brGDGTs (minor component) (Xiao et al., 2015), and its IIIa/IIIa' and IIa/IIa' ratios are 12.5 and 8.2, respectively (Fig. 3a, b). For the mixed sample of Soil-1 (soil) and MT4 (Mariana Trench), the mass spectrum showed two peaks for $m / z 1050$ (hexamethylated brGDGTs) as well as for $m / z 1036$ (pentamethylated brGDGTs) (Fig. 3e, f). The comparison of retention time among Soil-1, MT-4, and the mixed sample (Soil-1 + MT-4) revealed that the peaks of $m / z 1050$ and 1036 in MT-4 were pentamethylated 6-methyl brGDGTs $\left(\mathrm{IIa}^{\prime}\right)$ and hexamethylated 6-methyl brGDGTs (IIIa'), respectively, eluting after 5-methyl brGDGTs (Fig. 3). This structural assignment was corroborated by an intermediate level of 5-methyl / 6-methyl brGDGT ratio in the mixed sample (1.4 for $m / z, 1050$ and 7.4 for $m / z$ 1036) compared to that in Soil-1 (12.5 and 8.2, respectively) and MT-4 (0 for both) (Fig. 3).

In the sediment core of the Mariana Trench, the brGDGTs were constantly dominated by 6-methyl isomers $(82.25 \%$ $86.91 \%)$. The fractional abundance of 5-methyl brGDGTs, however, was too low to be quantified. BrGDGT IIIa' was the dominant compound ( $73.40 \pm 2.39 \%$ of total brGDGTs), followed by brGDGT Ia $(12.46 \pm 1.14 \%)$ and brGDGT $\mathrm{IIa}^{\prime}(10.45 \pm 1.20 \%)$. The proportion of cyclic compounds (brGDGT Ib, Ic, IIb') was only $3.69 \pm 0.75 \%$, resulting in a low level of \#rings tetra $(0.26 \pm 0.04)$. The classification based on the number of methyl groups showed the dominance of hexamethylated brGDGTs $(73.53 \pm 2.56 \%)$ over tetramethylated $(15.43 \pm 1.53 \%)$ and pentamethylated $(11.04 \pm 1.49 \%)$ brGDGTs.
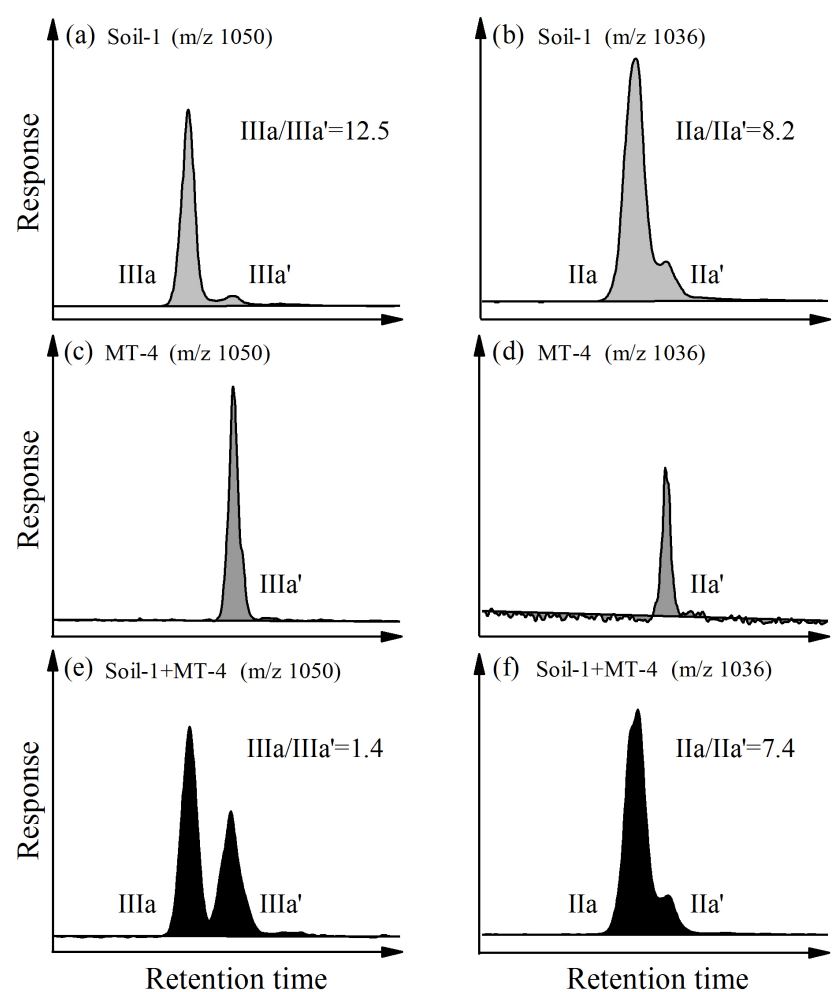

(f) Soil-1+MT-4 (m/z 1036)

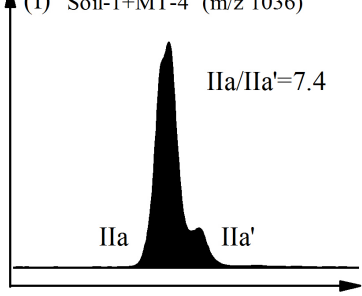

Retention time

Figure 3. Extracted ion chromatograms (EICs) of $m / z 1050$ (a, c, e) and $m / z 1036(\mathbf{b}, \mathbf{d}, \mathbf{f})$ showing separation of 5-methyl and 6methyl brGDGTs in soil (a, b), Mariana Trench sediment (c, d), and combined soil and sediment (e, f).

\section{Discussion}

\subsection{In situ production of 6-methyl brGDGTs in the Mariana Trench}

To our knowledge, there are only two studies reporting GDGTs in the Mariana Trench. Guan et al. (2019) investigated iGDGT distribution in the surface sediments (4900$7068 \mathrm{~m}$ depth) from the southern Mariana Trench, while Ta et al. (2019) analyzed iGDGTs and brGDGTs in two sediment cores (ca. $5400 \mathrm{~m}$ depth) in the subduction plate of the Mariana Trench. However, neither of these studies separated the 5- and 6-methyl brGDGTs. Our improved chromatographic method demonstrated the strong predominance of 6-methyl brGDGTs and the absence of 5-methyl brGDGTs in the Mariana Trench sediments. In order to decipher the mechanism of producing such unique compositions of brGDGTs, the source assessment is needed.

Multiple lines of evidence (i.e., $\delta^{13} \mathrm{C}_{\mathrm{OC}}, \mathrm{OC} / \mathrm{TN}$ ratio, and biomarkers) support an in situ production of brGDGTs in the Mariana Trench. The $\delta^{13} \mathrm{COC}_{\mathrm{OC}}$ and $\mathrm{OC} / \mathrm{TN}$ ratio are widely used indicators to distinguish terrestrial vs. marine OC. Generally, marine algae and bacteria are protein-rich and have a OC/TN ratio of 4 to 10 , whereas vascular land plants are cellulose and lignin-rich and have a OC/TN ratio of 20 or 
Table 2. Fractional abundance of brGDGTs and iGDGTs in the Mariana Trench sediments.

\begin{tabular}{|c|c|c|c|c|c|c|c|c|c|c|c|c|c|c|c|c|c|}
\hline $\begin{array}{l}\text { Sample } \\
\text { ID }\end{array}$ & $\begin{array}{r}\text { Ia } \\
(\%)\end{array}$ & $\begin{array}{r}\mathrm{Ib} \\
(\%)\end{array}$ & $\begin{array}{r}\text { Ic } \\
(\%)\end{array}$ & $\begin{array}{r}\text { IIa } \\
(\%)\end{array}$ & $\begin{array}{l}\mathrm{IIa}^{\prime} \\
(\%)\end{array}$ & $\begin{array}{r}\mathrm{IIb} \\
(\%)\end{array}$ & $\begin{array}{l}\mathrm{IIb}^{\prime} \\
(\%)\end{array}$ & $\begin{array}{r}\text { IIc } \\
(\%)\end{array}$ & $\begin{array}{l}\mathrm{IIc}^{\prime} \\
(\%)\end{array}$ & $\begin{array}{l}\text { IIIa } \\
(\%)\end{array}$ & $\begin{array}{r}\mathrm{IIIa}^{\prime} \\
(\%)\end{array}$ & $\begin{array}{l}\text { IIIb } \\
(\%)\end{array}$ & $\begin{array}{r}\mathrm{IIIb}^{\prime} \\
(\%)\end{array}$ & $\begin{array}{l}\text { IIIc } \\
(\%)\end{array}$ & $\begin{array}{r}\mathrm{IIIc}^{\prime} \\
(\%)\end{array}$ & $\begin{array}{r}\text { brGDGTs } \\
(\%)\end{array}$ & $\begin{array}{r}\text { iGDGTs } \\
(\%)\end{array}$ \\
\hline MT1 & 13.6 & 2.7 & 1.5 & 0.0 & 10.4 & 0.0 & 0.0 & 0.0 & 0.0 & 0.0 & 71.8 & 0.0 & 0.0 & 0.0 & 0.0 & 3.2 & 96.8 \\
\hline MT2.5 & 13.5 & 2.4 & 1.6 & 0.0 & 12.1 & 0.0 & 1.3 & 0.0 & 0.0 & 0.0 & 69.0 & 0.0 & 0.0 & 0.0 & 0.0 & 2.0 & 98.0 \\
\hline MT3.5 & 11.1 & 1.4 & 0.6 & 0.0 & 9.5 & 0.0 & 0.6 & 0.0 & 0.0 & 0.0 & 76.2 & 0.0 & 0.6 & 0.0 & 0.0 & 1.5 & 98.5 \\
\hline MT4.5 & 14.2 & 1.4 & 0.9 & 0.0 & 9.2 & 0.0 & 0.4 & 0.0 & 0.0 & 0.0 & 73.9 & 0.0 & 0.0 & 0.0 & 0.0 & 1.5 & 98.5 \\
\hline MT5.5 & 11.1 & 2.0 & 0.8 & 0.0 & 10.3 & 0.0 & 0.8 & 0.0 & 0.0 & 0.0 & 75.0 & 0.0 & 0.0 & 0.0 & 0.0 & 1.5 & 98.5 \\
\hline MT6.5 & 11.2 & 2.1 & 0.9 & 0.0 & 9.1 & 0.0 & 0.0 & 0.0 & 0.0 & 0.0 & 76.0 & 0.0 & 0.8 & 0.0 & 0.0 & 1.7 & 98.3 \\
\hline MT7.5 & 13.4 & 1.5 & 1.0 & 0.0 & 11.3 & 0.0 & 1.2 & 0.0 & 0.0 & 0.0 & 71.5 & 0.0 & 0.0 & 0.0 & 0.0 & 1.4 & 98.6 \\
\hline MT8.5 & 13.0 & 2.2 & 1.1 & 0.0 & 12.7 & 0.0 & 0.0 & 0.0 & 0.0 & 0.0 & 70.9 & 0.0 & 0.0 & 0.0 & 0.0 & 1.4 & 98.6 \\
\hline MT9.5 & 11.8 & 2.0 & 0.7 & 0.0 & 9.2 & 0.0 & 0.0 & 0.0 & 0.0 & 0.0 & 76.3 & 0.0 & 0.0 & 0.0 & 0.0 & 1.7 & 98.3 \\
\hline MT10.5 & 11.8 & 1.8 & 1.0 & 0.0 & 10.6 & 0.0 & 1.0 & 0.0 & 0.4 & 0.0 & 73.3 & 0.0 & 0.0 & 0.0 & 0.0 & 1.7 & 98.3 \\
\hline
\end{tabular}

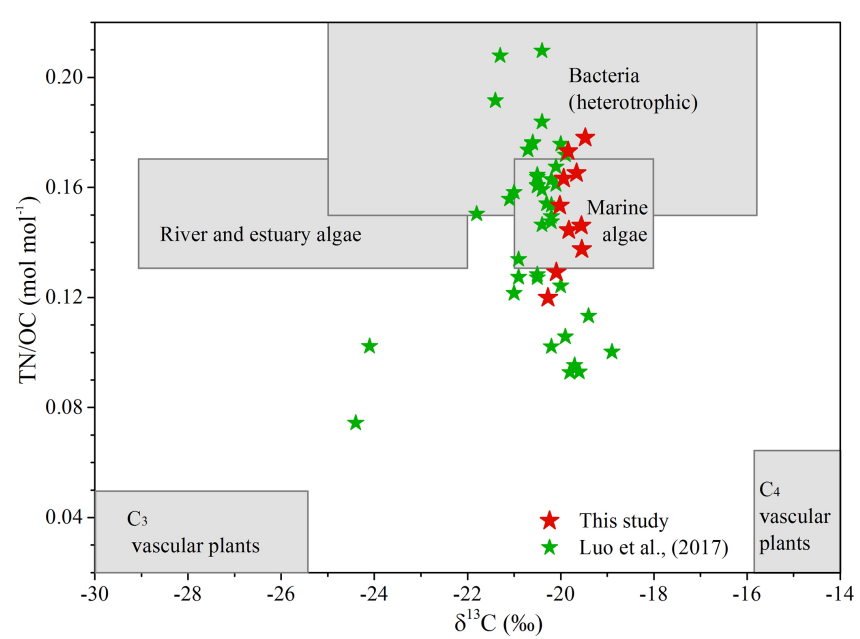

Figure 4. Plot of $\delta^{13} \mathrm{C}_{\mathrm{OC}}$ versus $\mathrm{TN} / \mathrm{OC}$ for core sediments from the Mariana Trench (MT). Included in this graph are different compositional ranges of $\mathrm{C}_{3}$ vascular plants, $\mathrm{C}_{4}$ vascular plants, bacteria, river and estuary phytoplankton, and marine phytoplankton sources. The compositional range of different end members was cited from Goñi et al. (2006) and Hu et al. (2016). The red stars and green stars denote data from this study and Luo et al. (2017), respectively.

greater (Meyers, 1994). Due to different carbon sources and photosynthetic pathways, the typical $\delta^{13} \mathrm{C}_{\mathrm{OC}}$ is between ca. $-22 \%$ and $-20 \%$ for marine organisms (Meyers, 1994) and ca. $-27 \%$ o for terrestrial $C_{3}$ plants (O'Leary, 1988). Sediments from the Mariana Trench yielded high $\delta^{13} \mathrm{C}_{\mathrm{OC}}$ values $(-19.82 \pm 0.25 \%$ o $)$ and a low OC/TN ratio $(6.72 \pm 0.84)$, suggesting that sedimentary $\mathrm{OC}$ is of a pure marine source (Fig. 4). Thus, the terrestrial contribution to the brGDGT pool in the Mariana Trench is insignificant.

Long-distance dust transport might deliver brGDGTs from continent to open ocean. Unfortunately, there is no report about brGDGTs for eolian dust in the Mariana Trench region. Weijers et al. (2014) compared the composition of brGDGTs between marine sediments and atmospheric dust in the equatorial west African coast, and their great difference suggested an in situ production rather than dust input for brGDGTs in the marine sediments. Here, we compared the brGDGT compositions between the Mariana Trench sediments and terrestrial samples reported in literature (Fig. 5). Relative to the Mariana Trench sediments (brGDGT Ia $12.46 \pm 1.14 \%$, 5methyl brGDGTs $\sim 0$, brGDGT IIIa' $73.40 \pm 2.39 \%$ ), those terrestrial samples had significantly higher proportions of brGDGT Ia (soil $37.52 \pm 25.91 \%$, peat $59.40 \pm 21.19 \%$, river $15.38 \pm 2.97 \%$ ) and 5-methyl brGDGTs (soil 23.56 \pm $14.83 \%$, peat $34.04 \pm 19.18 \%$, river $33.25 \pm 8.51 \%$ ) but lower proportions of brGDGT IIIa' (soil $4.89 \pm 4.82 \%$, peat $4.86 \pm 4.68 \%$, river $11.68 \pm 4.40 \%)(p<0.005)$ (Fig. 5). In addition, those terrestrial samples are globally distributed, many of which are from the inner Asian continent, a major source area for dust in the North Pacific (Husar et al., 2001). Thus, brGDGTs in the Mariana Trench sediments are unlikely derived from atmospheric dusts.

Low BIT index of the Mariana Trench sediments $(0.03 \pm$ 0.01 ; Fig. 6) is similar to distal marine sediments (an average of 0.04) (Schouten et al., 2013; Weijers et al., 2014), again suggesting insignificant terrestrial inputs in the Mariana Trench. By compilation of globally distributed 1354 soils and 589 marine sediments, Xiao et al. (2016) proposed the $\left(\mathrm{IIIa}+\mathrm{IIIa}^{\prime}\right) /\left(\mathrm{IIa}+\mathrm{IIa}^{\prime}\right)$ ratio as an indicator for the source of brGDGTs, which was $<0.59$ in $90 \%$ of soils and $0.59-0.92$ and $>0.92$ in marine sediments with and without significant terrestrial inputs, respectively. For the Mariana Trench sediments, the $\left(\mathrm{IIIa}+\mathrm{IIIa}^{\prime}\right) /\left(\mathrm{IIa}+\mathrm{IIa}^{\prime}\right)$ ratio varied between 5.68 and $8.33(7.13 \pm 0.98)$ (Fig. 6). Such a high $\left(\mathrm{IIIa}+\mathrm{IIIa}^{\prime}\right) /\left(\mathrm{IIa}+\mathrm{IIa}^{\prime}\right)$ ratio suggests a predominant marine source for brGDGTs in the Mariana Trench sediments.

Overall, the bulk geochemical parameters, the composition of brGDGTs, and the BIT index unanimously support the in situ product rather than terrestrial input for brGDGTs in Mariana Trench sediments. 

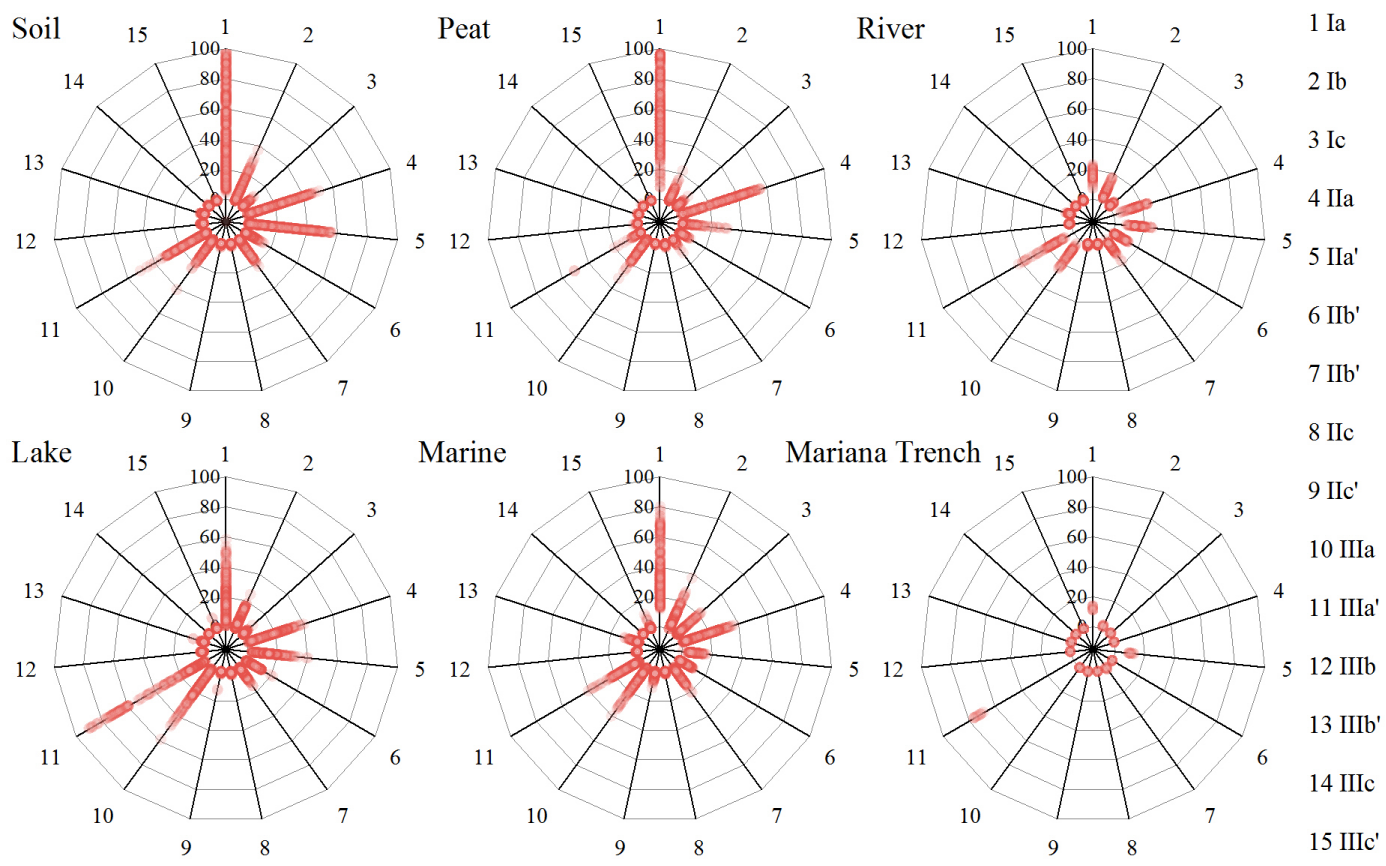

Figure 5. Comparisons of distribution of 15 brGDGT compounds in soil $(n=634)$, peat $(n=473)$, river $(n=88)$, lake $(n=410)$, marine $(n=415)$, and Mariana Trench $(n=11)$ samples.

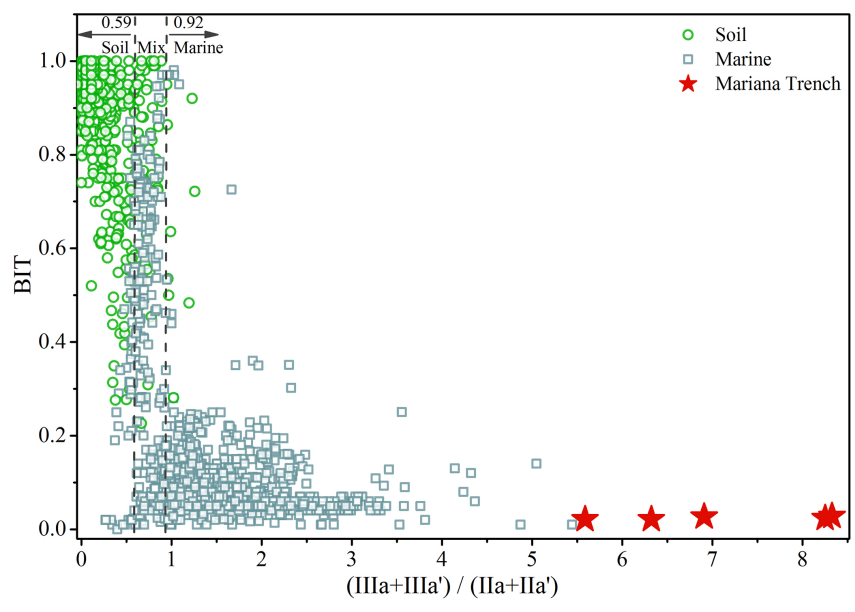

Figure 6. Relationship between the (IIIa $\left.+\mathrm{IIIa}^{\prime}\right) /\left(\mathrm{IIa}+\mathrm{IIa}^{\prime}\right)$ index and the BIT index of the Mariana Trench sediments (star) and globally distributed soil (circle) and marine samples (square). The dashed lines represent the upper limit of production in the terrestrial realm and the lower limit of production in the marine realm defined by Xiao et al. (2016).

\subsection{High proportion of brGDGT IIIa' as a common phenomenon in marine environments}

Not only the Mariana Trench but also continental margins showed relatively high proportions of hexamethylated 6methyl brGDGTs in sediments. Dearing Crampton-Flood et al. (2018) investigated brGDGTs and bulk properties of or- ganic matter in a sediment core from the North Sea Basin. The OC content, $\delta^{13} \mathrm{C}_{\mathrm{OC}}$ value, BIT, and \#rings tetra $_{\text {index in- }}$ dicated a transition from the predominant marine $\mathrm{OC}$ in the Pliocene to the predominant terrestrial OC in the Pleistocene. Correspondingly, the proportion of brGDGT IIIa' was significantly higher in the Pliocene $(8.06 \pm 1.92 \%)$ than the Pleistocene $(5.16 \pm 0.83 \%)$ and exhibited a significant correlation with $\delta^{13} \mathrm{C}_{\mathrm{OC}}\left(R^{2}=0.68, p<0.001\right)$ and the BIT index $\left(R^{2}=0.46, p<0.001\right)$ (Fig. 7a, b, c). Similar to the North Sea Basin, the proportion of GDGT IIIa' in the Kara Sea also showed a significant correlation with $\delta^{13} \mathrm{C}_{\mathrm{OC}}$ $\left(R^{2}=0.34 ; p<0.001\right)$ and the BIT index $\left(R^{2}=0.50 ; p<\right.$ 0.001 ) in a $303 \mathrm{~cm}$ sediment core covering at least the past $13.3 \times 10^{3}$ years (Fig. 7d, e, f) (De Jonge et al., 2016). These results suggest that brGDGTs synthesized by marine organisms comprise higher fractional abundance of hexamethylated 6-methyl brGDGTs.

Besides temporal variations in sediment cores, the fractional abundance of 6-methyl brGDGTs also changed from land to sea in modern samples. Warden et al. (2016) analyzed brGDGTs along a transect from the Tagus River to the deep ocean off the Portuguese margin. Along this transect, the BIT index significantly decreased from 0.9 to $<0.1$, reflecting an increase in marine contribution to the sedimentary OC pool (Fig. 7h). Meanwhile, the proportion of brGDGT IIIa' ${ }^{\prime}$ substantially increased from $11.07 \pm 2.62 \%$ to $29.31 \pm 6.45 \%$, and brGDGT IIIa' became the dominant compound of brGDGTs (Fig. 7g). In surface sediments of the Berau River delta, the \#rings $s_{\text {tetra }}$ index, an indicator of the 

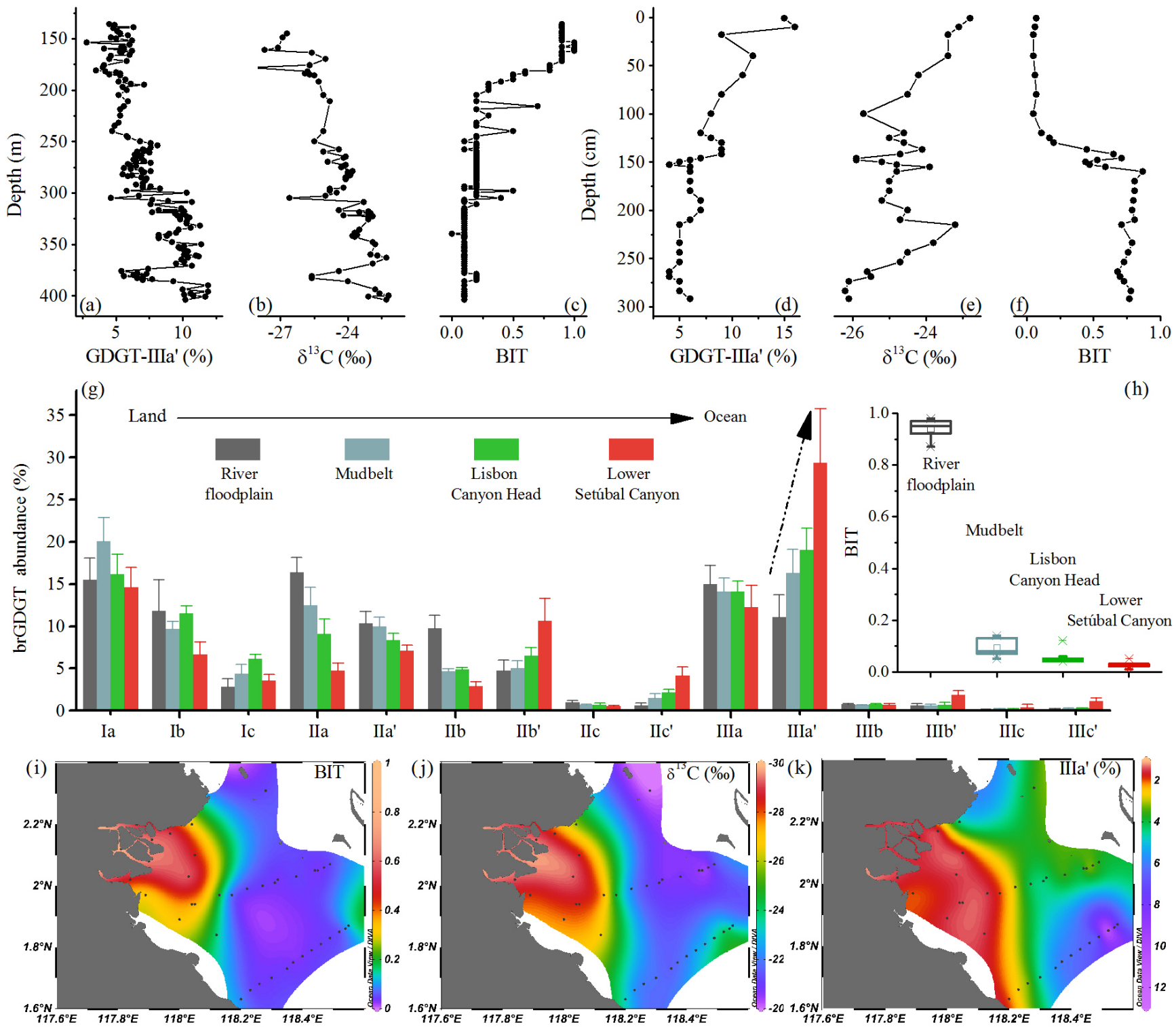

Figure 7. Vertical profiles of (a) the proportion of GDGT IIIa', (b) $\delta^{13} \mathrm{C}_{\mathrm{OC}}$, and (c) BIT index of a marine sediment core from the North Sea Basin (Dearing Crampton-Flood et al., 2018). Vertical profiles of (d) the proportion of GDGT IIIa', (e) $\delta^{13} \mathrm{C}_{\mathrm{OCC}}$, and (f) BIT index of a marine sediment core from the Kara Sea (De Jonge et al., 2016). Spatial distribution patterns of (g) average distribution of brGDGTs and (h) BIT index in the transect from the land to the ocean off the Portuguese coast (river floodplain, mudbelt, Lisbon canyon head, and lower Setúbal canyon) (Warden et al., 2016). Isosurface plots of (i) BIT index, (j) $\delta^{13} \mathrm{C}_{\mathrm{OC}}$, and (k) the proportion of GDGT IIIa' of the surface sediments from the Berau River delta (Sinninghe Damsté, 2016).

source of brGDGTs, showed a marked increase from the river mouth (0.22) to the shelf break (0.83) (Sinninghe Damsté, 2016), while the proportion of brGDGT IIIa' increased seawards, presenting similar distribution patterns as the $\delta^{13} \mathrm{C}_{\mathrm{OC}}$ and BIT index (Fig. 7i, j, k).

In sum, the studies for the Kara Sea (De Jonge et al., 2016), the North Sea Basin (Dearing Crampton-Flood et al., 2018), the Tagus River basin (Warden et al., 2016), and the Berau River delta (Sinninghe Damsté, 2016) show enhanced fractional abundance of 6-methyl brGDGTs (particularly IIIa') as marine influence was intensified. These findings, along with the strong predominance of brGDGT IIIa' in the Mariana Trench sediments, suggest that the high proportion of brGDGT IIIa' in total brGDGTs is a common phenomenon in marine environments where in situ production of brGDGTs is significant. 


\subsection{Potential mechanisms to produce high fractional abundance of brGDGT IIIa'}

A survey of brGDGTs in globally distributed soils suggested that brGDGT-producing microbes could adjust their membrane lipid compositions in response to changing environmental conditions, reflected by the increase in cyclization degree of brGDGTs and the shift from 5- to 6methyl group with increasing $\mathrm{pH}$ and decreasing methylation of brGDGTs with temperature (Weijers et al., 2007b; De Jonge et al., 2014a; Ding et al., 2015; Xiao et al., 2015). This adaption mechanism may be extrapolated to marine brGDGT-producing organisms. In the Mariana Trench, in situ production yielded brGDGTs with a strong predominance of brGDGT IIIa' (>69\%), low proportion of cyclopentane-containing brGDGTs $(<10 \%)$, and low level of the \#rings tetra $_{\text {index }}(<0.32)$. These characters seem in contrast to the previous result that the fractional abundance of cyclopentane-containing brGDGTs is positively correlated with pH (Sinninghe Damsté, 2016). This difference can be explained by two reasons. First, the isomerization of brGDGTs is more efficient in response to changing $\mathrm{pH}$ compared to the cyclization of brGDGTs (Ding et al., 2015). Based on the global soil dataset, the soil $\mathrm{pH}$ presents stronger correlations with the isomerization of branched tetraether index (IBT; Xiao et al., 2015) than with the \#rings tetra $_{\text {in- }}$ dex as well as the cyclization index $\left(\mathrm{CBT}_{5 \mathrm{me}}\right)$ (De Jonge et al., 2014a). Meanwhile, global soils with $\mathrm{pH}>8(n=$ 58) are characterized by higher fractional abundance of 6methyl brGDGTs $(68.22 \pm 10.41 \%)$ than the cyclopentanecontaining brGDGTs $(16.69 \pm 9.43 \%)$. Thus, weakly alkaline sediment and seawater $(\mathrm{pH} \sim 8.0)$ may be important factors for producing more 6-methyl hexamethylated brGDGTs in the Mariana Trench. The second explanation is the effect of low temperature. Marine microbes tend to produce more hexamethylated brGDGTs at low temperature (Sinninghe Damsté, 2016), thus reducing the proportion of cyclic tetramethylated and pentamethylated brGDGTs. The ternary diagram, plotted with fractional abundance of tera-, penta-, and hexamethylated brGDGTs (Fig. 8), shows that brGDGTs in the Mariana Trench sediments comprise high fractional abundance of hexamethylated brGDGTs $(73.53 \pm 2.56 \%)$. Given these facts, we propose that low temperature and high $\mathrm{pH}$ in deep-sea environments are responsible for the production of brGDGTs with a high degree of methylation and predominance of 6-methyl brGDGTs, especially brGDGT IIIa' .

In situ production of brGDGTs may take place in the water column, sediments, or both. Sinninghe Damsté (2016) suggested that in situ production of brGDGTs was a widespread phenomenon in shelf sediments that was especially pronounced at $50-300 \mathrm{~m}$ depths. The extended dataset (63$5521 \mathrm{~m}$ depths) showed a large variability for the degree of cyclization of brGDGTs (Weijers et al., 2014), suggesting that the brGDGTs are mainly produced in sediments where the $\mathrm{pH}$ of porewater is more variable than that of overlying

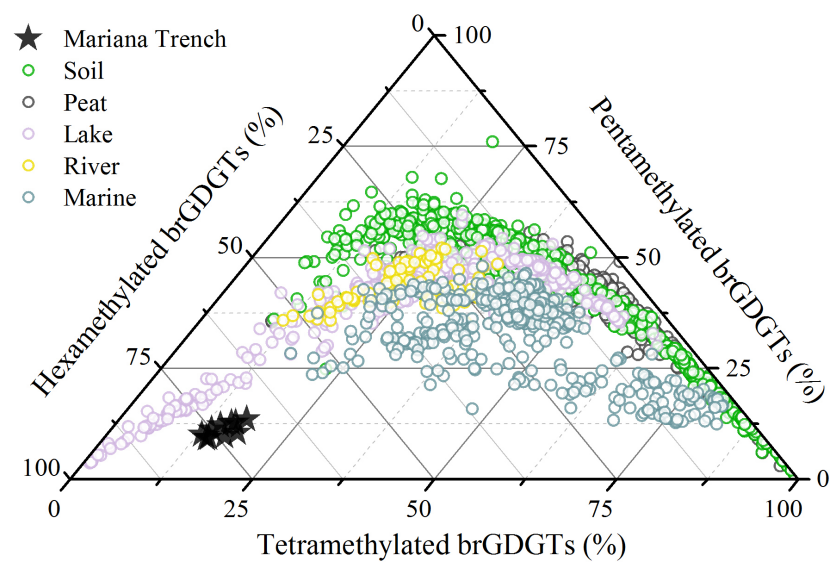

Figure 8. Ternary diagram showing the fractional abundances of tetra-, penta-, and hexamethylated brGDGTs. The compiled dataset includes globally distributed soil, peat, lake, river, and marine samples, as well as the Mariana Trench sediments.

seawaters. However, in the Mariana Trench sediments, the degree of cyclization fell in a narrow range ( 0.26 to 0.32$)$. As a result, both water column and sediments are possibly where brGDGTs are produced.

The bottom of the Mariana Trench is an extreme environment, characterized by high hydrostatic pressure $(>100 \mathrm{MPa})$, low temperature $\left(\mathrm{ca} .2{ }^{\circ} \mathrm{C}\right)$, and darkness (Jamieson, 2015). In addition, the surface waters in the Mariana Trench region are extremely oligotrophic, leading to a low sinking flux of particulate organic matter to the seafloor. Under such extreme conditions, unique microbes may have evolved, such as proliferation of hydrocarbon-degrading bacteria (Liu et al., 2019). These deep-sea microbes may have different responses to changing ambient temperature and $\mathrm{pH}$ than their shallow-dwelling counterparts, and they thus produce brGDGTs with different compositions. Investigations of microbial community and intact polar lipids are needed for understanding the source and environmental implication of brGDGTs in the Mariana Trench and other marine settings.

\subsection{Deciphering brGDGT provenance in marine sediments}

There are increasing concerns about the robustness of brGDGT-based proxies. Deciphering the provenance of brGDGTs is prerequisite for the application of brGDGTbased proxies. In continental margins, intense land-sea interaction occurs, resulting in the complex composition and sources of brGDGTs (De Jonge et al., 2016; Sinninghe Damsté, 2016; Dearing Crampton-Flood et al., 2018). Our study highlights that marine in situ production of brGDGTs tends to exhibit higher fractional abundance of brGDGT IIIa relative to terrestrial brGDGTs. However, there is an overlap for the fractional abundance of brGDGT IIIa' between 


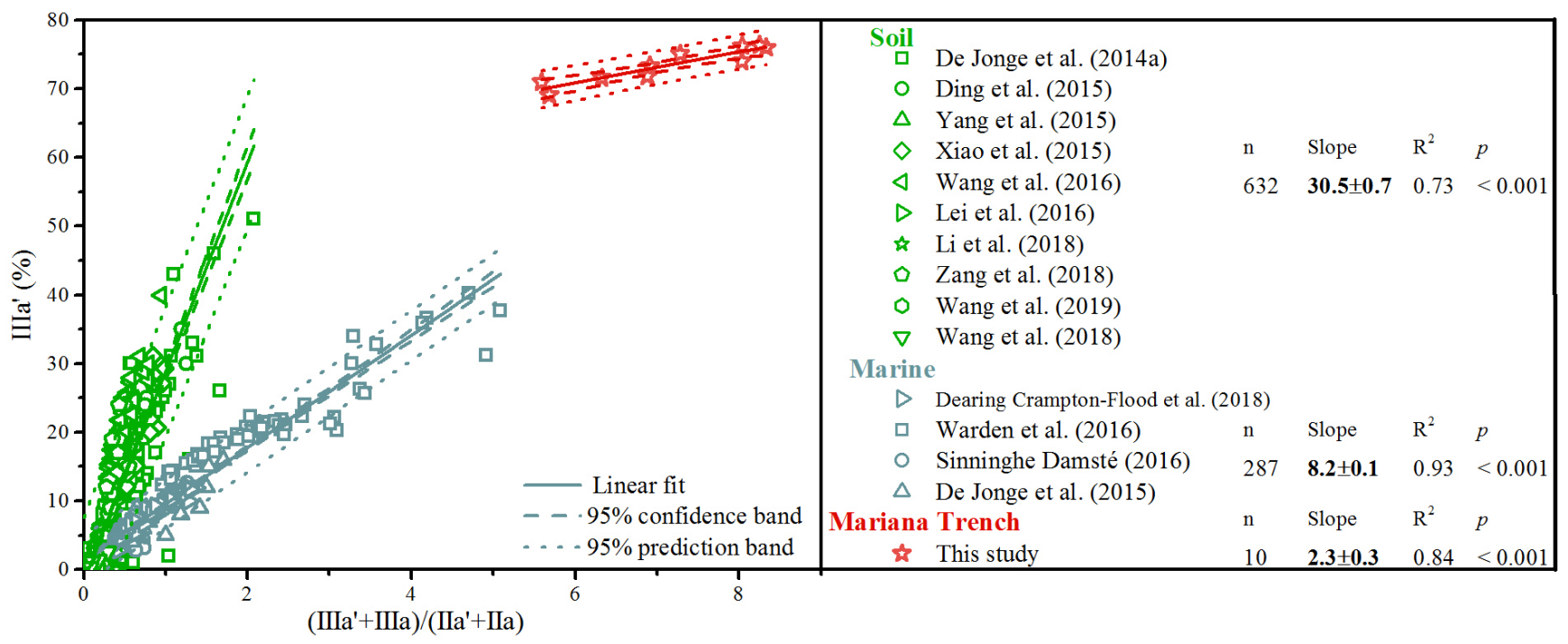

Figure 9. Scatterplots of the (IIIa $\left.+\mathrm{IIIa}^{\prime}\right) /\left(\mathrm{IIa}+\mathrm{IIa}^{\prime}\right)$ ratio versus the proportion of brGDGT IIIa' in globally distributed soils and marine sediments. The solid, dashed, and dotted lines denote the linear fit, $95 \%$ confidence band, and $95 \%$ prediction band of concatenated data, respectively. The number of samples, slope, $R^{2}$, and $p$ values of calibration are for the global distributed soils, marine sediments, and Mariana Trench sediments.

soil and marine sediments (De Jonge et al., 2014a). Xiao et al. (2016) developed the (IIIa + IIIa')/(IIa $\left.+\mathrm{IIa}^{\prime}\right)$ ratio to distinguish brGDGTs from soils $(<0.59)$ and marine sediments with terrestrial influence $(0.59-0.92)$ and without terrestrial influence $(>0.92)$. However, some overlaps still exist between soils and marine sediments (Fig. 9). In order to circumvent this problem, we combine the (IIIa + IIIa $) /\left(\mathrm{IIa}_{+}+\mathrm{IIa}^{\prime}\right)$ ratio and fractional abundance of brGDGT IIIa' to evaluate the source of brGDGTs (Fig. 9). Specifically, the cross plot of the (IIIa $\left.+\mathrm{IIIa}^{\prime}\right) /\left(\mathrm{IIa}+\mathrm{IIa}^{\prime}\right)$ ratio and fractional abundance of brGDGT IIIa' reveals that the slope of global soils $(30.5 \pm 0.7)$ is significantly larger than that of marine sediments with terrestrial influence $(8.2 \pm 0.1)$, and both are significantly larger than the slope of the Mariana Trench sediments without significant terrestrial influence $(2.3 \pm 0.3)$ (Fig. 9).

The unique composition of brGDGTs in the Mariana Trench has significant implications for the brGDGT-based proxies. As a setting remote from landmass, the Mariana Trench provides an opportunity to distinguish marine in situ production from a terrestrial origin of brGDGTs that usually muddles the interpretation of shelf sediments. However, it is unclear what the similarity and differences are for brGDGTproducing microbes and their response to environmental factors between the Mariana Trench and continental shelf. In addition, the weight contribution to the brGDGT pool from sediments and the water column remains elusive. Since factors such as nutrients, particle loading, bacterial community, and oceanographic parameters (e.g., oxygenation, salinity, currents) vary significantly between the shelf and trench as well as among different hadal trenches, the brGDGT- producing microbes are likely different. Therefore, investigation of brGDGTs in multiple hadal trenches and shallow marine regions is needed to decipher their source and environmental control, which are beneficial for accurate application of the brGDGT-based proxies such as MBT, CBT, and BIT.

\section{Conclusions}

Our study represents the first investigation for 5-methyl and 6-methyl brGDGTs in the hadal trench, enabling us to draw four conclusions.

The Mariana Trench sediments are characterized by the strong predominance of 6-methyl brGDGTs (84.57 \pm $1.53 \%$ of total brGDGTs), especially brGDGT IIIa' $(73.40 \pm$ $2.39 \%$ ), whereas 5-methyl brGDGTs are below the detection limit. This unique feature has never been reported and attributed to the combined effect of insignificant terrestrial influence, alkaline seawater, and low subsurface temperature in the Mariana Trench.

High brGDGT $\left(\mathrm{IIIa}+\mathrm{IIIa}^{\prime}\right) /\left(\mathrm{IIa}^{2} \mathrm{IIa}^{\prime}\right)$ ratios $(7.13 \pm$ $0.98)$, enriched $\delta^{13} \mathrm{C}_{\mathrm{OC}}$ signatures $(-19.82 \pm 0.25 \%)$, low $\mathrm{OC} / \mathrm{TN}$ ratios $(6.72 \pm 0.84)$, low BIT index $(0.03 \pm 0.01)$, high abundance of 6-methyl brGDGTs, and absence of 5methyl brGDGTs support an in situ production of brGDGTs in the Mariana Trench sediments.

BrGDGTs in sediments from the Mariana Trench and continental margins comprise a higher proportion of hexamethylated 6-methyl brGDGTs with intensified marine influence. The slope of fractional abundance of brGDGT IIIa' and the $\left(\mathrm{IIIa}+\mathrm{IIIa}^{\prime}\right) /\left(\mathrm{IIa}+\mathrm{IIa}^{\prime}\right)$ index can be used to deci- 
pher terrestrial and marine provenance of brGDGTs. Since in situ production of the predominant hexamethylated 6-methyl brGDGTs influences the robustness of brGDGT-based proxies, this study provides a new way to estimate brGDGT sources and holds some promise in reducing uncertainty of brGDGT-based paleoenvironmental proxies.

The uniqueness of the Mariana Trench in that it is remote from any landmass allows us to distinguish marine in situ production from terrestrial origin of brGDGTs. However, it is unclear how comparable this unique site is to shallow marine settings and other hadal trenches. Therefore, comparison studies of brGDGTs for different hadal trenches as well as between hadal and non-hadal sites are recommended.

Data availability. Data have been made available through figshare: https://doi.org/10.6084/m9.figshare.9896120.v1 (Xiao et al., 2019).

Supplement. The supplement related to this article is available online at: https://doi.org/10.5194/bg-17-2135-2020-supplement.

Author contributions. WX and YX developed the study design. Fieldwork for this study was conducted by YX. WX, YW, YL, XZ, and LS conducted the experiments and data analyses. All authors contributed to data interpretation. WX and YX compiled and processed all presented data and wrote the manuscript.

Competing interests. The authors declare that they have no conflict of interest.

Acknowledgements. Samples were obtained during cruises by the RV Zhang Jian. We are grateful to the captains and crews for their excellent support in obtaining the samples. Weicheng Cui, Binbin Pan, and Jiasong Fang are thanked for assistance in sampling and GDGT analysis. The two anonymous reviewers and associate editor (Silvio Pantoja) are thanked for constructive comments.

Financial support. This research has been supported by the National Natural Science Foundation of China (grant nos. 41976030, 41676058), State Key Laboratory of Marine Geology, Tongji University (grant no. MGK202003), and Qingdao National Laboratory for Marine Science and Technology (grant no. QNLM2016ORP0208).

Review statement. This paper was edited by Silvio Pantoja and reviewed by two anonymous referees.

\section{References}

Buckles, L. K., Weijers, J. W. H., Verschuren, D., and Sinninghe Damsté, J. S.: Sources of core and intact branched tetraether membrane lipids in the lacustrine environment: Anatomy of Lake Challa and its catchment, equatorial East Africa, Geochim. Cosmochim. Ac., 140, 106-126, https://doi.org/10.1016/j.gca.2014.04.042, 2014.

Dang, X., Yang, H., Naafs, B. D. A., Pancost, R. D., and Xie, S.: Evidence of moisture control on the methylation of branched glycerol dialkyl glycerol tetraethers in semiarid and arid soils, Geochim. Cosmochim. Ac., 189, 24-36, https://doi.org/10.1016/j.gca.2016.06.004, 2016a.

Dang, X. Y., Xue, J. T., Yang, H., and Xie, S.C.: Environmental impacts on the distribution of microbial tetraether lipids in Chinese lakes with contrasting $\mathrm{pH}$ : Implications for lacustrine paleoenvironmental reconstructions, Sci. China Earth Sci., 59, 939-950, https://doi.org/10.1007/s11430-015-5234-z, 2016b.

Dang, X., Ding, W., Yang, H., Pancost, R. D., Naafs, B. D. A., Xue, J., Xiao, L., Lu, J., and Xie, S.: Different temperature dependence of the bacterial brGDGT isomers in 35 Chinese lake sediments compared to that in soils, Org. Geochem., 119, 72-79, https://doi.org/10.1016/j.orggeochem.2018.02.008, 2018.

Dearing Crampton-Flood, E., Peterse, F., Munsterman, D., and Sinninghe Damsté, J. S.: Using tetraether lipids archived in North Sea Basin sediments to extract North Western European Pliocene continental air temperatures, Earth Planet. Sc. Lett., 490, 193 205, https://doi.org/10.1016/j.eps1.2018.03.030, 2018.

De Jonge, C., Hopmans, E. C., Stadnitskaia, A., Rijpstra, W. I. C., Hofland, R., Tegelaar, E., and Sinninghe Damsté, J. S.: Identification of novel penta- and hexamethylated branched glycerol dialkyl glycerol tetraethers in peat using HPLC$\mathrm{MS}^{2}$, GC-MS and GC-SMB-MS, Org. Geochem., 54, 78-82, https://doi.org/10.1016/j.orggeochem.2012.10.004, 2013.

De Jonge, C., Hopmans, E. C., Zell, C. I., Kim, J.-H., Schouten, S., and Sinninghe Damsté, J. S.: Occurrence and abundance of 6-methyl branched glycerol dialkyl glycerol tetraethers in soils: Implications for palaeoclimate reconstruction, Geochim. Cosmochim. Ac., 141, 97-112, https://doi.org/10.1016/j.gca.2014.06.013, 2014a.

De Jonge, C., Stadnitskaia, A., Hopmans, E. C., Cherkashov, G., Fedotov, A., and Sinninghe Damsté, J. S.: In situ produced branched glycerol dialkyl glycerol tetraethers in suspended particulate matter from the Yenisei River, Eastern Siberia, Geochim. Cosmochim. Ac., 125, 476-491, https://doi.org/10.1016/j.gca.2013.10.031, 2014b.

De Jonge, C., Stadnitskaia, A., Hopmans, E. C., Cherkashov, G., Fedotov, A., Streletskaya, I. D., Vasiliev, A. A., and Sinninghe Damsté, J. S.: Drastic changes in the distribution of branched tetraether lipids in suspended matter and sediments from the Yenisei River and Kara Sea (Siberia): Implications for the use of brGDGT-based proxies in coastal marine sediments, Geochim. Cosmochim. Ac., 165, 200-225, https://doi.org/10.1016/j.gca.2015.05.044, 2015.

De Jonge, C., Stadnitskaia, A., Cherkashov, G., and Sinninghe Damsté, J. S.: Branched glycerol dialkyl glycerol tetraethers and crenarchaeol record post-glacial sea level rise and shift in source of terrigenous brGDGTs in the Kara Sea (Arctic Ocean), Org. Geochem., 92, 42-54, https://doi.org/10.1016/j.orggeochem.2015.11.009, 2016. 
De Rosa, M. and Gambacorta, A.: The lipids of archaebacteria, Prog. Lipid Res., 27, 153-175, https://doi.org/10.1016/01637827(88)90011-2, 1988.

Ding, S., Xu, Y., Wang, Y., He, Y., Hou, J., Chen, L., and He, J.S.: Distribution of branched glycerol dialkyl glycerol tetraethers in surface soils of the Qinghai-Tibetan Plateau: implications of brGDGTs-based proxies in cold and dry regions, Biogeosciences, 12, 3141-3151, https://doi.org/10.5194/bg-12-31412015, 2015.

Ding, S., Schwab, V. F., Ueberschaar, N., Roth, V. N., Lange, M., $\mathrm{Xu}$, Y., Gleixner, G., and Pohnert, G.: Identification of novel 7-methyl and cyclopentanyl branched glycerol dialkyl glycerol tetraethers in lake sediments, Org. Geochem., 102, 52-58, https://doi.org/10.1016/j.orggeochem.2016.09.009, 2016.

Freymond, C. V., Peterse, F., Fischer, L. V., Filip, F., Giosan, L., and Eglinton, T. I.: Branched GDGT signals in fluvial sediments of the Danube River basin: Method comparison and longitudinal evolution, Org. Geochem., 103, 88-96, https://doi.org/10.1016/j.orggeochem.2016.11.002, 2016.

Fryer, P.: Evolution of the Mariana Convergent Plate Margin System, Rev. Geophys., 34, 89-125, https://doi.org/10.1029/95RG03476, 1996.

Glud, R. N., Wenzhofer, F., Middelboe, M., Oguri, K., Turnewitsch, R., Canfield, D. E., and Kitazato, H.: High rates of microbial carbon turnover in sediments in the deepest oceanic trench on Earth, Nat. Geosci., 6, 284-288, https://doi.org/10.1038/ngeo1773, 2013.

Goñi, M. A., Monacci, N., Gisewhite, R., Ogston, A., Crockett, J., and Nittrouer, C.: Distribution and sources of particulate organic matter in the water column and sediments of the Fly River Delta, Gulf of Papua (Papua New Guinea), Estuar. Coast. Shelf S., 69, 225-245, https://doi.org/10.1016/j.ecss.2006.04.012, 2006.

Guan, H., Chen, L., Luo, M., Liu, L., Mao, S., Ge, H., Zhang, M., Fang, J., and Chen, D.: Composition and origin of lipid biomarkers in the surface sediments from the southern Challenger Deep, Mariana Trench, Geosci. Front., 10, 351-360, https://doi.org/10.1016/j.gsf.2018.01.004, 2019.

Herfort, L., Schouten, S., Boon, J. P., Woltering, M., Baas, M., Weijers, J. W. H., and Sinninghe Damsté, J. S.: Characterization of transport and deposition of terrestrial organic matter in the southern North Sea using the BIT index, Limnol. Oceanogr., 51, 21962205, https://doi.org/10.4319/lo.2006.51.5.2196, 2006.

Hopmans, E. C., Weijers, J. W. H., Schefuss, E., Herfort, L., Sinninghe Damsté, J. S., and Schouten, S.: A novel proxy for terrestrial organic matter in sediments based on branched and isoprenoid tetraether lipids, Earth Planet. Sc. Lett., 224, 107-116, https://doi.org/10.1016/j.eps1.2004.05.012, 2004.

Hopmans, E. C., Schouten, S., and Sinninghe Damsté, J. S.: The effect of improved chromatography on GDGT-based palaeoproxies, Org. Geochem., 93, 1-6, https://doi.org/10.1016/j.orggeochem.2015.12.006, 2016.

Hu, L., Shi, X., Bai, Y., Qiao, S., Li, L., Yu, Y., Yang, G., Ma, D., and Guo, Z.: Recent organic carbon sequestration in the shelf sediments of the Bohai Sea and Yellow Sea, China, J. Marine Syst., 155, 50-58, https://doi.org/10.1016/j.jmarsys.2015.10.018, 2016.

Huguet, C., Hopmans, E. C., Feboayala, W., Thompson, D. H., Sinninghe Damsté, J. S., and Schouten, S.: An improved method to determine the absolute abundance of glycerol dibiphy- tanyl glycerol tetraether lipids, Org. Geochem., 37, 1036-1041, https://doi.org/10.1016/j.orggeochem.2006.05.008, 2006.

Husar, R. B., Tratt, D. M., Schichtel, B. A., Falke, S. R., Li, F., Jaffe, D., Gassó, S., Gill, T., Laulainen, N. S., Lu, F., Reheis, M. C., Chun, Y., Westphal, D., Holben, B. N., Gueymard, C., McKendry, I., Kuring, N., Feldman, G. C., McClain, C., Frouin, R. J., Merrill, J., DuBois, D., Vignola, F., Murayama, T., Nickovic, S., Wilson, W. E., Sassen, K., Sugimoto, N., and Malm, W. C.: Asian dust events of April 1998, J. Geophys. Res.-Atmos., 106, 18317-18330, https://doi.org/10.1029/2000JD900788, 2001.

Jamieson, A.: The hadal zone: life in the deepest oceans, Cambridge University Press, UK, 2015.

Kim, J. H., Schouten, S., Buscail, R., Ludwig, W., Bonnin, J., Sinninghe Damsté, J. S., and Bourrin, F.: Origin and distribution of terrestrial organic matter in the NW Mediterranean (Gulf of Lions): Exploring the newly developed BIT index, Geochem. Geophy. Geosy., 7, 220-222, https://doi.org/10.1029/2006GC001306, 2006.

Knappy, C. S., Nunn, C. E. M., Morgan, H. W., and Keely, B. J.: The major lipid cores of the archaeon Ignisphaera aggregans: implications for the phylogeny and biosynthesis of glycerol monoalkyl glycerol tetraether isoprenoid lipids, Extremophiles, 15, 517528, https://doi.org/10.1007/s00792-011-0382-3, 2011.

Lei, Y., Yang, H., Dang, X., Zhao, S., and Xie, S.: Absence of a significant bias towards summer temperature in branched tetraether-based paleothermometer at two soil sites with contrasting temperature seasonality, Org. Geochem., 94, 83-94, https://doi.org/10.1016/j.orggeochem.2016.02.003, 2016.

Li, J., Naafs, B. D. A., Pancost, R. D., Yang, H., Deng, L., and Xie, S.: Distribution of branched tetraether lipids in ponds from Inner Mongolia, NE China: Insight into the source of brGDGTs, Org. Geochem., 112, 127-136, https://doi.org/10.1016/j.orggeochem.2017.07.005, 2017.

Li, Y., Zhao, S., Pei, H., Shi, Q., Zang, J., Dang, X., and Yang, H.: Distribution of glycerol dialkyl glycerol tetraethers in surface soils along an altitudinal transect at cold and humid Mountain Changbai: Implications for the reconstruction of paleoaltimetry and paleoclimate, Sci. China Earth Sci., 61, 925-939, https://doi.org/10.1007/s11430-017-9168-9, 2018.

Liu, J., Zheng, Y., Lin, H., Wang, X., Li, M., Liu, Y., Yu, M., Zhao, M., Pedentchouk, N., Lea-Smith, D. J., Todd, J. D., Magill, C. R., Zhang, W.-J., Zhou, S., Song, D., Zhong, H., Xin, Y., Yu, M., Tian, J., and Zhang, X.-H.: Proliferation of hydrocarbondegrading microbes at the bottom of the Mariana Trench, Microbiome, 7, 47, https://doi.org/10.1186/s40168-019-0652-3, 2019.

Liu, X., Zhu, C., Wakeham, S. G., and Hinrichs, K.: In situ production of branched glycerol dialkyl glycerol tetraethers in anoxic marine water columns, Mar. Chem., 166, 1-8, https://doi.org/10.1016/j.marchem.2014.08.008, 2014.

Loomis, S. E., Russell, J. M., and Sinninghe Damsté, J. S.: Distributions of branched GDGTs in soils and lake sediments from western Uganda: Implications for a lacustrine paleothermometer, Org. Geochem., 42, 739-751, https://doi.org/10.1016/j.orggeochem.2011.06.004, 2011.

Luo, M., Gieskes, J., Chen, L., Shi, X., and Chen, D.: Provenances, distribution, and accumulation of organic matter in the southern Mariana Trench rim and slope: Implication for carbon cycle and burial in hadal trenches, Mar. Geol., 386, 486-498, https://doi.org/10.1016/j.margeo.2017.02.012, 2017. 
Martin, C., Ménot, G., Thouveny, N., Davtian, N., AndrieuPonel, V., Reille, M., and Bard, E.: Impact of human activities and vegetation changes on the tetraether sources in Lake St Front (Massif Central, France), Org. Geochem., 135, 38-52, https://doi.org/10.1016/j.orggeochem.2019.06.005, 2019.

Meyers, P. A.: Preservation of elemental and isotopic source identification of sedimentary organic matter, Chem. Geol., 144, 289302, https://doi.org/10.1016/0009-2541(94)90059-0, 1994.

Naafs, B. D. A., Inglis, G. N., Zheng, Y., Amesbury, M. J., Biester, H., Bindler, R., Blewett, J., Burrows, M. A., Torres, D. D. C., and Chambers, F. M.: Introducing global peatspecific temperature and $\mathrm{pH}$ calibrations based on brGDGT bacterial lipids, Geochim. Cosmochim. Ac., 208, 285-301, https://doi.org/10.1016/j.gca.2017.01.038, 2017.

O'Leary, M. H.: Carbon isotopes in photosynthesis, Bioscience, 38, 328-336, https://doi.org/10.2307/1310735, 1988.

Peterse, F., Kim, J.-H., Schouten, S., Kristensen, D. K., Koç, N., and Sinninghe Damsté, J. S.: Constraints on the application of the MBT/CBT palaeothermometer at high latitude environments (Svalbard, Norway), Org. Geochem., 40, 692-699, https://doi.org/10.1016/j.orggeochem.2009.03.004, 2009.

Peterse, F., van der Meer, J., Schouten, S., Weijers, J. W. H., Fierer, N., Jackson, R. B., Kim, J. H., and Sinninghe Damsté, J. S.: Revised calibration of the MBT-CBT paleotemperature proxy based on branched tetraether membrane lipids in surface soils, Geochim. Cosmochim. Ac., 96, 215-229, https://doi.org/10.1016/j.gca.2012.08.011, 2012.

Qin, W., Carlson, L. T., Armbrust, E. V., Devol, A. H., Moffett, J. W., Stahl, D. A., and Ingalls, A. E.: Confounding effects of oxygen and temperature on the $\mathrm{TEX}_{86}$ signature of marine Thaumarchaeota, P. Natl. Acad. Sci. USA, 112, 10979-10984, https://doi.org/10.1073/pnas.1501568112, 2015.

Russell, J. M., Hopmans, E. C., Loomis, S. E., Liang, J., and Sinninghe Damsté, J. S.: Distributions of 5- and 6-methyl branched glycerol dialkyl glycerol tetraethers (brGDGTs) in East African lake sediment: Effects of temperature, $\mathrm{pH}$, and new lacustrine paleotemperature calibrations, Org. Geochem., 117, 56-69, https://doi.org/10.1016/j.orggeochem.2017.12.003, 2018.

Schouten, S., Hopmans, E. C., Baas, M., Boumann, H., Standfest, S., Könneke, M., Stahl, D. A., and Sinninghe Damsté, J. S.: Intact Membrane Lipids of "Candidatus Nitrosopumilus maritimus," a Cultivated Representative of the Cosmopolitan Mesophilic Group I Crenarchaeota, Appl. Environ. Microb., 74, 2433-2440, https://doi.org/10.1128/AEM.01709-07, 2008.

Schouten, S., Hopmans, E. C., and Sinninghe Damsté, J. S.: The organic geochemistry of glycerol dialkyl glycerol tetraether lipids: A review, Org. Geochem., 54, 19-61, https://doi.org/10.1016/j.orggeochem.2012.09.006, 2013.

Sinninghe Damsté, J. S.: Spatial heterogeneity of sources of branched tetraethers in shelf systems: The geochemistry of tetraethers in the Berau River delta (Kalimantan, Indonesia), Geochim. Cosmochim. Ac., 186, 13-31, https://doi.org/10.1016/j.gca.2016.04.033, 2016.

Sinninghe Damsté, J. S., Hopmans, E. C., Pancost, R. D., Schouten, S., and Geenevasen, J. A. J.: Newly discovered non-isoprenoid dialkyl diglycerol tetraether lipids in sediments, Chem. Commun., 23, 1683-1684, https://doi.org/10.1039/B004517I, 2000.

Sinninghe Damsté, J. S., Stefan, S., Hopmans, E. C., Duin, A. C. T., Van and Geenevasen, J. A. J.: Crenarchaeol: the characteris- tic core glycerol dibiphytanyl glycerol tetraether membrane lipid of cosmopolitan pelagic crenarchaeota, J. Lipid Res., 43, 16411651, https://doi.org/10.1194/jlr.M200148-JLR200, 2002.

Sinninghe Damsté, J. S., Ossebaar, J., Schouten, S., and Verschuren, D.: Altitudinal shifts in the branched tetraether lipid distribution in soil from Mt. Kilimanjaro (Tanzania): Implications for the MBT/CBT continental palaeothermometer, Org. Geochem., 39, 1072-1076, https://doi.org/10.1016/j.orggeochem.2007.11.011, 2008.

Sinninghe Damsté, J. S., Ossebaar, J., Abbas, B., Schouten, S., and Verschuren, D.: Fluxes and distribution of tetraether lipids in an equatorial African lake: Constraints on the application of the $\mathrm{TEX}_{86}$ palaeothermometer and BIT index in lacustrine settings, Geochim. Cosmochim. Ac., 73, 4232-4249, https://doi.org/10.1016/j.gca.2009.04.022, 2009.

Sinninghe Damsté, J. S., Rijpstra, W. I., Hopmans, E. C., Weijers, J. W., Foesel, B. U., Overmann, J., and Dedysh, S. N.: 13,16-Dimethyl octacosanedioic acid (iso-diabolic acid), a common membrane-spanning lipid of Acidobacteria subdivisions 1 and 3, Appl. Environ. Microb., 77, 4147-4154, https://doi.org/10.1128/aem.00466-11, 2011.

Soelen, E. E. V., Kim, J. H., Santos, R. V., Dantas, E. L., Almeida, F. V. D., Pires, J. P., Roddaz, M., and Sinninghe Damsté, J. S.: A $30 \mathrm{Ma}$ history of the Amazon River inferred from terrigenous sediments and organic matter on the Ceará Rise, Earth Planet Sc. Lett., 474, 40-48, https://doi.org/10.1016/j.eps1.2017.06.025, 2017.

Ta, K., Peng, X., Xu, H., Du, M., Chen, S., Li, J., and Zhang, C.: Distributions and Sources of Glycerol Dialkyl Glycerol Tetraethers in Sediment Cores From the Mariana Subduction Zone, J. Geophys. Res.-Biogeo., 124, 857-869, https://doi.org/10.1029/2018jg004748, 2019.

Tierney, J. E. and Russell, J. M.: Distributions of branched GDGTs in a tropical lake system: Implications for lacustrine application of the MBT/CBT paleoproxy, Org. Geochem., 40, 1032-1036, https://doi.org/10.1016/j.orggeochem.2009.04.014, 2009.

Wang, H., Liu, W., and Lu, H.: Appraisal of branched glycerol dialkyl glycerol tetraether-based indices for North China, Org. Geochem., 98, 118-130, https://doi.org/10.1016/j.orggeochem.2016.05.013, 2016.

Wang, M., Zong, Y., Zheng, Z., Man, M., Hu, J., and Tian, L.: Utility of brGDGTs as temperature and precipitation proxies in subtropical China, Sci. Rep., 8, 194, https://doi.org/10.1038/s41598017-17964-0, 2018.

Wang, M., Zheng, Z., Zong, Y., Man, M., and Tian, L.: Distributions of soil branched glycerol dialkyl glycerol tetraethers from different climate regions of China, Sci. Rep.-UK, 9, 2761, https://doi.org/10.1038/s41598-019-39147-9, 2019.

Warden, L., Kim, J.-H., Zell, C., Vis, G.-J., de Stigter, H., Bonnin, J., and Sinninghe Damsté, J. S.: Examining the provenance of branched GDGTs in the Tagus River drainage basin and its outflow into the Atlantic Ocean over the Holocene to determine their usefulness for paleoclimate applications, Biogeosciences, 13, 5719-5738, https://doi.org/10.5194/bg-13-5719-2016, 2016.

Weber, Y., Jonge, C. D., Rijpstra, W. I. C., Hopmans, E. C., Stadnitskaia, A., Schubert, C. J., Lehmann, M. F., Sinninghe Damsté, J. S., and Niemann, H.: Identification and carbon isotope composition of a novel branched GDGT isomer in lake sediments: Evidence for lacustrine branched 
GDGT production, Geochim. Cosmochim. Ac., 154, 118-129, https://doi.org/10.1016/j.gca.2015.01.032, 2015.

Weber, Y., Sinninghe Damsté, J. S., Zopfi, J., De Jonge, C., Gilli, A., Schubert, C. J., Lepori, F., Lehmann, M. F., and Niemann, H.: Redox-dependent niche differentiation provides evidence for multiple bacterial sources of glycerol tetraether lipids in lakes, P. Natl. Acad. Sci. USA, 115, 10926-10931, https://doi.org/10.1073/pnas.1805186115, 2018.

Weijers, J. W. H., Schefuß, E., Schouten, S., and Sinninghe Damsté, J. S.: Coupled thermal and hydrological evolution of tropical Africa over the last deglaciation, Science, 315, 1701-1704, https://doi.org/10.1126/science.1138131, 2007a.

Weijers, J. W. H., Schouten, S., Donker, J. C. V. D., Hopmans, E. C., and Sinninghe Damsté, J. S.: Environmental controls on bacterial tetraether membrane lipid distribution in soils, Geochim. Cosmochim. Ac., 71, 703-713, https://doi.org/10.1016/j.gca.2006.10.003, 2007b.

Weijers, J. W. H., Schefuß, E., Kim, J.-H., Sinninghe Damsté, J. S., and Schouten, S.: Constraints on the sources of branched tetraether membrane lipids in distal marine sediments, Org. Geochem., 72, 14-22, https://doi.org/10.1016/j.orggeochem.2014.04.011, 2014.

Wu, W., Zhao, L., Pei, Y., Ding, W., Yang, H., and Xu, Y.: Variability of tetraether lipids in Yellow River-dominated continental margin during the past eight decades: Implications for organic matter sources and river channel shifts, Org. Geochem., 60, 3339, https://doi.org/10.1016/j.orggeochem.2013.04.014, 2013.

Xiao, W., Xu, Y., Ding, S., Wang, Y., Zhang, X., Yang, H., Wang, G., and Hou, J.: Global calibration of a novel, branched GDGT-based soil pH proxy, Org. Geochem., 89-90, 56-60, https://doi.org/10.1016/j.orggeochem.2015.10.005, 2015.

Xiao, W., Wang, Y., Zhou, S., Hu, L., Yang, H., and Xu, Y.: Ubiquitous production of branched glycerol dialkyl glycerol tetraethers (brGDGTs) in global marine environments: a new source indicator for brGDGTs, Biogeosciences, 13, 5883-5894, https://doi.org/10.5194/bg-13-5883-2016, 2016.

Xiao, W., Wang, Y., Liu, Y., Zhang, X., Shi, L., and $\mathrm{Xu}, \mathrm{Y}$ : Raw data about brGDGTs in Mariana Trench and global environmental settings, Figshare, https://doi.org/10.6084/m9.figshare.9896120.v1, 2019.

Xie, S., Liu, X. L., Schubotz, F., Wakeham, S. G., and Hinrichs, K. U.: Distribution of glycerol ether lipids in the oxygen minimum zone of the Eastern Tropical North Pacific Ocean, Org. Geochem., 71, 60-71, https://doi.org/10.1016/j.orggeochem.2014.04.006, 2014.

$\mathrm{Xu}, \mathrm{Y} ., \mathrm{Ge}, \mathrm{H}$., and Fang, J.: Biogeochemistry of hadal trenches: Recent developments and future perspectives, Deep-Sea Res. Pt. II, 155, 19-26, https://doi.org/10.1016/j.dsr2.2018.10.006, 2018.

Yang, H., Pancost, R. D., Dang, X., Zhou, X., Evershed, R. P., Xiao, G., Tang, C., Gao, L., Guo, Z., and Xie, S.: Correlations between microbial tetraether lipids and environmental variables in Chinese soils: Optimizing the paleo-reconstructions in semiarid and arid regions, Geochim. Cosmochim. Ac., 126, 49-69, https://doi.org/10.1016/j.gca.2013.10.041, 2014.
Yang, H., Lü, X., Ding, W., Lei, Y., Dang, X., and Xie, S.: The 6-methyl branched tetraethers significantly affect the performance of the methylation index (MBT') in soils from an altitudinal transect at Mount Shennongjia, Org. Geochem., 82, 42-53, https://doi.org/10.1016/j.orggeochem.2015.02.003, 2015.

Zang, J., Lei, Y., and Yang, H.: Distribution of glycerol ethers in Turpan soils: implications for use of GDGT-based proxies in hot and dry regions, Front. Earth Sci., 12, 862-876, https://doi.org/10.1007/s11707-018-0722-z, 2018.

Zell, C., Kim, J.-H., Moreira-Turcq, P., Abril, G., Hopmans, E. C., Bonnet, M.-P., Sobrinho, R. L., and Sinninghe Damsté, J. S.: Disentangling the origins of branched tetraether lipids and crenarchaeol in the lower Amazon River: Implications for GDGT-based proxies, Limnol. Oceanogr., 58, 343-353, https://doi.org/10.4319/lo.2013.58.1.0343, 2013.

Zell, C., Kim, J.-H., Balsinha, M., Dorhout, D., Fernandes, C., Baas, M., and Sinninghe Damsté, J. S.: Transport of branched tetraether lipids from the Tagus River basin to the coastal ocean of the Portuguese margin: consequences for the interpretation of the $\mathrm{MBT}^{\prime} / \mathrm{CBT}$ paleothermometer, Biogeosciences, 11, 5637-5655, https://doi.org/10.5194/bg-11-5637-2014, 2014a.

Zell, C., Kim, J. H., Hollander, D., Lorenzoni, L., Baker, P., Silva, C. G., Nittrouer, C., and Sinninghe Damsté, J. S.: Sources and distributions of branched and isoprenoid tetraether lipids on the Amazon shelf and fan: Implications for the use of GDGT-based proxies in marine sediments, Geochim. Cosmochim. Ac., 139, 293-312, https://doi.org/10.1016/j.gca.2014.04.038, 2014b.

Zeng, Z., Liu, X.-L., Farley, K. R., Wei, J. H., Metcalf, W. W., Summons, R. E., and Welander, P. V.: GDGT cyclization proteins identify the dominant archaeal sources of tetraether lipids in the ocean, P. Natl. Acad. Sci. USA, 116, 22505, https://doi.org/10.1073/pnas.1909306116, 2019.

Zhang, C., Wang, J., Wei, Y., Zhu, C., Huang, L., and Dong, H.: Production of branched tetraether lipids in the lower Pearl River and estuary: effects of extraction methods and impact on bGDGT proxies, Front. Microbiol., 2, 274, https://doi.org/10.3389/fmicb.2011.00274, 2012.

Zhu, C., Weijers, J. W. H., Wagner, T., Pan, J. M., Chen, J. F., and Pancost, R. D.: Sources and distributions of tetraether lipids in surface sediments across a large riverdominated continental margin, Org. Geochem., 42, 376-386, https://doi.org/10.1016/j.orggeochem.2011.02.002, 2011. 